\title{
Potential of MACROPHYTe FOR Removing ARSENic FROM AQUEOUS SOLUTION ${ }^{1}$
}

\author{
Potencial de Remoção de Arsênio de Solução Aquosa por Macrofita
}

GUIMARAES, F.P. ${ }^{2}$, AGUIAR, R. ${ }^{2 \dagger}$, OLIVEIRA, J.A. ${ }^{2}$, SILVA, J.A.A. ${ }^{3}$, and KARAM, D. ${ }^{3}$

\begin{abstract}
The potential of three aquatic macrophytes, Azoll caroliniana, Salvinia minima and Lemna gibba, was evaluated in this work aimed at selection of plants to be used in remediation of environments contaminated by arsenic (As). The experiments were carried out in a greenhouse during six days in pots containing Hoagland solution ( $1 / 4$ ionic strength) at As concentrations of $0.5 ; 2.5$ and $5.0 \mathrm{mg} \mathrm{L}^{-1}$. The three species showed greater As accumulation as the concentration of the metalloid in solution increased. However, a reduction was detected in fresh and dry mass gain when the plants were exposed to high As concentrations. The macrophytes showed differences in efficiency of removal of As in solution. A. caroliniana, S. minima and $L$. gibba accumulated, on average, 0.130; 0.200; and $1.397 \mathrm{mg} \mathrm{mDM}^{-1}$, respectively, when exposed to $5.0 \mathrm{mg} \mathrm{L}^{-1}$ of As. The macrophytes absorbed a greater quantity of As in solution with low phosphate content. The greater As concentration in L. gibba tissues lowered the chlorophyll and carotenoid contents as shown by the high chlorosis incidence. Lemna gibba also exhibited a decrease in leaf size, with the total chlorophyll and carotenoid synthesis not being affected by As in A. caroliniana. This species exhibited purplish leaves with high concentration of anthocyanin, whose presence suggested association to phosphate deficiency. Marginal necrosis occurred on S. minima floating leaves, with the released daughter-plants not showing any visual symptoms during the treatment. The percentage of As removed from the solution decreased when the plants were exposed to high concentrations of the pollutant. Among the three species studied, only $L$. gibba could be considered an As hyper-accumulator. The use of this plant species for remediation of aquatic environments was shown to be limited and requires further investigation.
\end{abstract}

Keywords: bio-remediation, phyto-remediation, aquatic plants, pollutant.

RESUMO - O potencial de três macrófitas aquáticas - Azolla caroliniana, Salvinia mínima $e$ Lemna gibba - foi avaliado neste estudo, com vistas à seleção de plantas para remediação de ambientes contaminados com arsênio (As). Os experimentos foram conduzidos em casa de vegetação durante seis dias, em vasos contendo solução Hoagland (1/4 força iônica) e As nas concentrações de 0,5; 2,5 e 5,O mg $\mathrm{L}^{-1}$. As três espécies mostraram acúmulo crescente de As tanto quanto a concentração do metalóide na solução foi aumentada. No entanto, foi detectada redução no ganho de massa fresca e seca quando as plantas foram expostas a altas concentrações de As. As três espécies de macrófitas mostraram diferenças na eficiência de remoção de As na solução. A. caroliniana, S. minima e L. gibba acumularam, em média, 0,130, 1,200 e 1,397 $\mathrm{mg} \mathrm{mDM}^{-1}$ de As, respectivamente, quando expostas a 5,0 mg $\mathrm{L}^{-1}$. As macrófitas absorveram maior quantidade de As na solução com baixo indice de fosfato. Quanto maior a concentração de As nos tecidos da L. gibba, menor foi o conteúdo de clorofila e carotenoide, mostrado pela alta incidência de clorose. Lemna gibba também apresentou diminuição no tamanho da folha e As não afetou a sintese total de clorofila e carotenoide em A. caroliniana. Esta espécie apresentou folhas arroxeadas com alta concentração de antocianina cuja presença sugere associação à deficiência de fosfato. A necrose marginal ocorreu nas folhas flutuantes de S. minima, e as plantas-filha não mostraram nenhum sintoma visual. A porcentagem de As removida da solução pelas plantas foi reduzida quando estas foram expostas a altas

Recebido para publicação em 25.3.2012 e aprovado em 25.6.2012.

2 Plant Biology Department, Universidade Federal de Viçosa, PH Rolfs Av s/n, 36570-000 Viçosa, Minas Gerais, Brazil; ${ }^{3}$ Brazilian Agricultural Research Corporation - Maize and Shorgum, Rod. MG 424 - Km 45, 35701-970 Sete Lagoas, Minas Gerais, Brazil, $<$ karam@cnpms.embrapa.br>.

Planta Daninha, Viçosa-MG, v. 30, n. 4, p. 683-696, 2012 
concentrações do poluente. Das três espécies estudadas, somente $\boldsymbol{L}$. gibba pode ser considerada como hiperacumuladora de As, porém sua utilização para remediar ambientes aquáticos contaminados com As mostrou-se limitada e exige investigação mais aprofundada.

Palavras-chave: biorremediação, fitorremediação, plantas aquáticas, poluente.

\section{INTRODUCTION}

The introduction of heavy metals into the environment poses a major challenge to contemporary society, because such contaminants are highly persistent and difficult to remove. Unlike most organic contaminants, heavy metals cannot be degraded or detoxified by living beings, and hence they become a pollution problem over time (Oliveira et al., 2010). The use of physical-chemical methods to decontaminate aquatic environments requires constant and expensive maintenance, especially in large volumes of water (Aksorn \& Visoottiviseth, 2004). Phytoremediation processes include rhyzofiltration, a specific type of this technology which consists in using the plant root system to decontaminate polluted aquatic environments. This process is advantageous because aquatic plants grow quickly, producing a great deal of biomass; also, they have a fibrous root system that provides a large contact area with the pollutant. In addition to those characteristics, plants with remediation potential should be able to remove pollutants, as well as accumulate, hyper-accumulate, translocate and concentrate high amounts of certain toxic elements in their above ground/harvestable parts (Rahman \& Hasegawa, 2011). The remediation process performed by plants includes phytoextraction, phytoestabilization, phytovolatilization, phytotransformation and rhizofiltration (Jacques et al., 2007).

Among the various inorganic contaminants, arsenic (As) has received great attention from governmental authorities and civil society because of its toxic potential for humans. This metalloid can be found in different chemical forms in nature: organic and inorganic, such as arsenate, arsenite, arsine and elemental form, which have dissimilar oxidation states $(+5 ;+3 ;-3$ and 0 , respectively). This diversity results from its participation in biological, chemical and industrial processes (Dionisio et al., 2011). Chronic As exposure can cause skin diseases such as hyperpigmentation, gastrointestinal disorder, vascular disease, diabetes and peripheral neuropathies. Additionally, it can increase the risk for various types of cancers (Rodrigues \& Malafaia, 2008, 2010).

Arsenic releasing occurs through natural and anthropogenic processes, for example, volcanic activity and wastes from mining of gold, silver, cobalt, nickel, lead, copper and antimony (Matschullat et al., 2000; Meharg \& Hartley-Whitaker, 2002), for which the separation technologies and environmental fate are incipient.

Phytoremediation technology, especially rhizofiltration, has encouraged many researchers to investigate the potential of different aquatic plant species for removal of toxic elements such as $\mathrm{B}, \mathrm{Cr}, \mathrm{Cu}, \mathrm{Hg}, \mathrm{Cd}, \mathrm{Ni}$, Se and As from bodies of water (Zayed et al., 1998; Qian et al., 1999; Zhu et al., 1999).

Metallic element absorption by plant cells is facilitated by mechanisms involving transporting proteins (Lasat, 2002). As a result of the structural similarity between arsenate and phosphate, As $(+5)$ is absorbed by plants through the same phosphate absorption sites (Graeme \& Pollack, 1998; Dembitsky \& Rezanka, 2003; Aksorn \& Visoottiviseth, 2004; Mkandawire \& Dudel, 2005). Its transport occurs via symport with $\mathrm{H}^{+}$protons (Raghothama, 1999, 2000).

In this study, three species of aquatic macrophytes were used (Azolla caroliniana, Salvinia minima and Lemna gibba) which, according to the literature, have shown potential for remediation of impacted aquatic environments (Jain et al., 1990; Outridge \& Hutchinson, 1991; Outridge et al., 1991; Zayed et al., 1998; Axtell et al., 2003; Mkandawire et al., 2004; Mkandawire \& Dudel, 2005). 
Azolla caroliniana is a small, floating, aquatic pteridophyte. It has few thin roots and overlapping bilobed leaves. Colonies of cyanobacteria from the genus Anabaena, which are important fixers of atmospheric nitrogen, thrive on the lower leaf lobes of the plant. Azolla caroliniana is widely distributed in the tropics and in the Americas, especially in still waters (Tryon \& Tryon, 1982). It grows quickly, a fact which justifies its use in phytoremediation research. Salvinia minima is another floating aquatic pteridophyte. Its ramets consist of two opposite floating leaves, joined by a central stem (rhizome), and its third submersed leaf is modified, forming a root-like system. Each individual can connect to new and/or old apical rhizomes, forming extensive carpets. It is a fast-growing plant found in lakes or rivers in various parts of the world (Tryon $\&$ Tryon, 1982). Lemna gibba is a small, floating aquatic monocotyledon. It is fast-growing and widely distributed in several parts of the world and easily adapts to various aquatic conditions. It also plays important role in extraction and accumulation of metals in aquatic environments (Zayed et al., 1998).

The objective of this study was to assess the potential of these three macrophyte species for As removal and accumulation and identify their potential use for remediation of environments contaminated by the metalloid.

\section{MATERIAL AND METHODS}

\section{Plant material}

The floating aquatic macrophytes A. caroliniana, S. minima and L. gibba were collected from tanks at the Botanical Garden of the Plant Biology Department at the Federal University of Viçosa, Viçosa, Minas Gerais State, Brazil, in January 2005.

Following disinfection with $1 \%$ sodium hypochlorite solution, plants were washed in deionized water and cultivated in a greenhouse on plastic trays containing Hoagland solution, $1 / 4$ ionic strength, $\mathrm{pH}$ 6.5 (Hoagland \& Arnon, 1950). Plants used in the experiments were derived from two mother plants, resulting in minimal genotypic and pre-experimental variations, following recommendations of Outridge \& Hutchinson (1991).

\section{Growth analysis}

The growth of the three macrophyte species in Hoagland solution was assessed during 10 days, using $0.5 \mathrm{~g}$ fresh mass from each species in 25 black pots containing $500 \mathrm{~mL}$ Hoagland solution. Five pots were removed every two days and plants taken to an oven at $70{ }^{\circ} \mathrm{C}$ for measurement of constant dry mass weight, which is used to analyze plant growth under greenhouse conditions. This experiment aimed to determine the growth capacity of the plants because fast growth and biomass production in a short time interval are pre-requisites to select and use plants for phytoremediation studies.

\section{Plant exposure to As}

The three macrophyte species were exposed to As in the form of sodium arsenate $\left(\mathrm{Na}_{2} \mathrm{HAsO}_{4} \cdot 7 \mathrm{H}_{2} \mathrm{O}\right.$, Isofar). Each species (1.5 g fresh mass per sample unit) was treated with the following As concentrations: 0; 0.5; 2.5 and $5.0 \mathrm{mg} \mathrm{L}^{-1}$ with five replications. The plants were cultivated in black pots containing $1.500 \mathrm{~mL}$ Hoagland solution in a greenhouse at the Plant Growth Unit. Salvinia minima and L. gibba were exposed to As for six days and A. caroliniana for five days. Minimum temperature in the greenhouse was $17^{\circ} \mathrm{C}$ and the maximum one was $38^{\circ} \mathrm{C}$. Solution $\mathrm{pH}$ was corrected to 6.5 every two days and the volume of water completed daily with deionized water to compensate for water loss through transpiration and evaporation (Aksorn \& Visoottiviseth, 2004).

Plants were weighed every two days to obtain their fresh mass, removed from the pots using a sieve and dried on paper towel, and then returned to their respective pots using a sieve.

At the end of the experiment, plants were washed in $1 \%$ nitric acid solution to remove the As adsorbed on their surface. The plants were dried in an oven at $70^{\circ} \mathrm{C}$ until dry mass was obtained. Dry mass was used for growth analysis and to determine the As absorbed from the solution. Initial dry mass 
was calculated from the mean of five replications. Each one contained $1.5 \mathrm{~g}$ of fresh mass per species (Cedergreen et al., 2004).

The plastic pots used in the experiment were lined with polyethylene plastic bags to prevent contamination and facilitate residue storage for later disposal in a specialized waste facility.

The experiments were carried out in a greenhouse using a complete randomized design; the pots were rotated daily.

\section{Effect of phosphate on arsenate absorption}

One gram of dry weight per sample unit of each one of the three species, was exposed to the constant As concentration equivalent to $0.032 \mu \mathrm{mol} \mathrm{L} \mathrm{L}^{-1}$ and to six phosphate concentrations: $0.008 ; 0.016 ; 0.031 ; 0.062$; $0.125 ; 0.25 \mu \mathrm{mol} \mathrm{L}^{-1}$. Three replications were used per treatment. Plants were acclimated at the different phosphate concentrations during two days. The solutions were changed later, with the previous phosphate concentrations being maintained and As being added to the medium. After 24 hours, the plants were dried in an oven at $70^{\circ} \mathrm{C}$ to obtain the dry mass and determine As concentration.

\section{As measurement in the plants}

Dry whole plants were digested in nitroperchloride solution $(1: 4, \mathrm{v} / \mathrm{v})$ until samples became transparent; the temperature wasnot allowed to exceed $100{ }^{\circ} \mathrm{C}$ in order to prevent As volatilization (Samecka-Cymerman \& Kempers, 1996; Zayed et al., 1998; HartleyWhitaker et al., 2001; Aksorn \& Visoottiviseth, 2004; Sivaci et al., 2004). Samples were then filtered and diluted in $25 \mathrm{~mL}$ distilled water. Total As concentration in tissues was assessed using Atomic Absorption Spectrometry (AAS 220 FS, Varian Australia) at the Department of Soils of the Federal University of Viçosa. As was determined using a $193.7 \mathrm{~nm}$ wavelength and $0.5 \mathrm{~nm}$ slit width.

\section{As removal efficiency}

Removal efficiency of As in solution was estimated through the percentage of As removed by the plants. The amount of
As in solution was considered as $100 \%$. Concentration of As absorbed by the plants (mg g DM${ }^{-1}$ ) was multiplied by the amount of dry mass produced during the period of exposure to the metalloid, thus producing the total amount of As removed from the solution.

\section{Determination of pigment content}

Total chlorophyll and carotenoid content was determined in $0.5 \mathrm{~g}$ fresh mass of A. caroliniana and L. gibba treated with different As concentrations. Extraction was performed using acetone $(80 \%)$ and a pinch of $\mathrm{CaCO}_{3}$ (Lichthenthaler, 1987). The absorbance was measured in a UV visible spectrophotometer (UVmini-1240. Shimadzu, Japan) at the wavelengths $470,646.8$ and $663.2 \mathrm{~nm}$. The total chlorophyll and carotenoid contents were determined from the equations described by Lichthenthaler (1987). Salvinia minima plants were not used in this experiment because of cultivation problems with the species.

Antocyanin was extracted from $1 \mathrm{~g}$ fresh mass of $A$. caroliniana, with $15 \mathrm{~mL}$ ethanol acidified with $\mathrm{HCl}$ (Kamperidou \& Vasilakakis, 2006). Samples were placed in a refrigerator for 14 hours. The extract absorbance was measured with a UV visible spectrophotometer (UVmini-1240. Shimadzu, Japan) at $512 \mathrm{~nm}$ wavelength. This determination was used only for this species because of the purpling color formed upon exposure to As.

\section{Symptomatology developed in response to As}

A photographic record of plants exposed to different As concentrations was made using a digital camera (Sony DSC-S60). A stereoscopic microscope was also used (Olympus, Micronal VM VMT, Brazil) to show visual damage to the aquatic macrophytes grown in solution containing As.

The damage caused by As $\left(5.0 \mathrm{mg} \mathrm{L}^{-1}\right)$ to the $A$. caroliniana and $L$. gibba leaves was examined by scanning electronic microscopy of the plant tissues. The plants were fixed in glutaraldehyde $(5 \%)$, post-fixed in osmium tetroxide $(2 \%)$ and, after several washings, were dehydrated in an ethanolic series. Samples 
were dehydrated using a critical point apparatus (CPD-030. Bal-tec, Germany). Afterwards, they were mounted on stubs and metalized with a metallization equipment (Model FDU-010, Balzers, Germany), attached to a cathode Spray Set (Model SCA-010). Plant material was observed under an electronic microscope (Model LEO 1430 VP, Zeiss, Germany) at the Federal University of Viçosa Microscopy Center.

\section{Statistical analysis}

The results were submitted to analysis of variance (ANOVA) at the level of $5 \%$ probability to assess whether or not the treatments influenced As absorption and to register any difference in fresh and dry mass gain by the species. The Tukey test was carried out to differentiate the effect of treatments, at $5 \%$ probability.

\section{RESULTS AND DISCUSSION}

\section{Plant growth assessment and fresh mass gain}

All three macrophytes (A. caroliniana, L. gibba and S. minima) showed an exponential growth when cultivated in Hoagland solution in a greenhouse within a 10-day period.

The fresh mass of the macrophytes exposed to As increased throughout the experimental period, showing an exponential increase in all As concentrations. As concentration of arsenic in solution increased, plant growth decreased. However, when exposed to the $5.0 \mathrm{mg} \mathrm{L}^{-1}$ As, Salvinia minima did not grow, unlike the other two species. A. caroliniana and L. gibba, when exposed to As $\left(0.5 \mathrm{mg} \mathrm{L}^{-1}\right)$, had similar growth to that of the controls. Also plants of macrophyte Nasturtium officinale R. Br., exposed to 3 and $5 \mu \mathrm{M}$ of As (III), were affected significantly, revealing chlorosis of leaves and the weakening of the stem (Otzurk et al., 2010).

\section{Dry mass gain}

Mean dry mass gain by each species was estimated from the amount of dry mass produced daily. Concentration of As influenced the dry mass gain of the macrophytes significantly (analysis of variance, 3 degrees of freedom, Tukey test). The greater As concentration, the lower the dry mass gain in A. caroliniana $(\mathrm{F}=5.88, \mathrm{p}=0.006618)$, S. minima $(\mathrm{F}=80.72, \mathrm{p}=0)$ and L. gibba $(\mathrm{F}=60.54, \mathrm{p}=0)$. Azolla caroliniana, exposed to 0.5 and $2.5 \mathrm{mg} \mathrm{L}^{-1}$ As, produced an average gain of 0.033 and $0.031 \mathrm{~g}$ dry mass per day. These values were equivalent to the dry mass of control plants $\left(0.033 \mathrm{~g} \mathrm{day}^{-1}\right)$ and were higher than the gain of $0.030 \mathrm{~g} \mathrm{day}^{-1}$ observed in plants exposed to the $5.0 \mathrm{mg} \mathrm{L}^{-1}$ As (Figure 1). Salvinia minima gained an average of $0.031 \mathrm{~g}$ dry mass per day, when exposed to $0.5 \mathrm{mg} \mathrm{L}^{-1} \mathrm{As}$, a value equivalent to that observed in the control plants $\left(0.031 \mathrm{~g} \mathrm{day}^{-1}\right)$. At 2.5 and $5.0 \mathrm{mg} \mathrm{L}^{-1} \mathrm{As}$, S. minima gained an average of 0.018 and $0.002 \mathrm{~g} \mathrm{day}^{-1}$ dry mass, respectively. Such values are lower than those observed in the other plants (Figure 1). Lemna gibba had the same growth pattern as that of $S$. minima, in terms of decrease in dry mass gain. This species produced mean gains of $0.0023,0.020$, 0.010 and $0.002 \mathrm{~g} \mathrm{day}^{-1}$ when submitted to treatments $0.0,0.5,2.5$ and $5.0 \mathrm{mg} \mathrm{L}^{-1} \mathrm{As}$, respectively (Figure 1). Mkandawire \& Dudel (2005) found several positive results for accumulating metalloids under laboratory and field conditions by species of the family Lemnaceae in wastewater.

The higher As in solution the greater the concentration detected of the metalloid in A. caroliniana (Anova, $\mathrm{df}=3, \mathrm{~F}=38.832, \mathrm{p}<0$ ), S. minima (Anova, $\mathrm{df}=3, \mathrm{~F}=20.353, \mathrm{p}=0.00001$ )

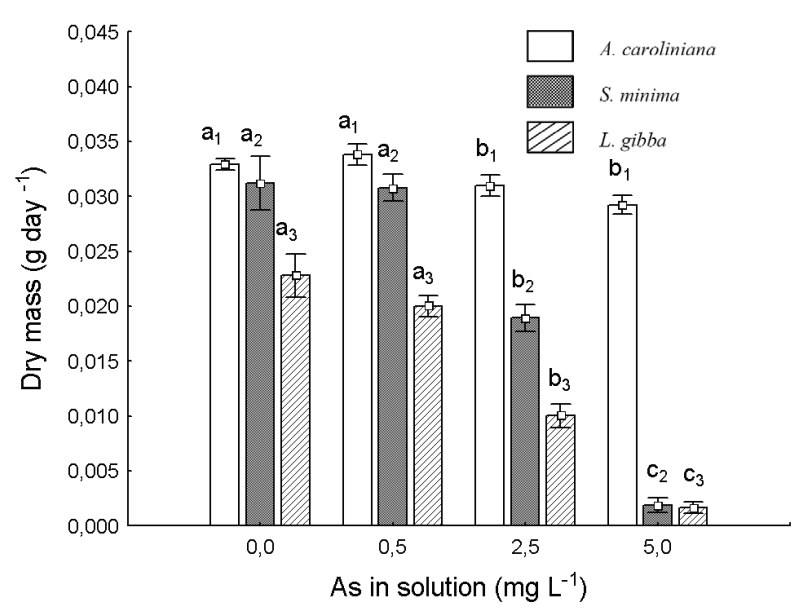

Figure 1 - Dry mass gain under different As concentrations. Bars represent standard errors. Different letters indicate different means by Tukey test. 
and L. gibba (Anova, df=3, $\mathrm{F}=664.173, \mathrm{p}<0$ ), as shown in Figure 2. Azolla caroliniana accumulated 0.065, 0.122 and $0.130 \mathrm{mg} \mathrm{g} \mathrm{DM}^{-1}$ on average, in the treatments with $0.5 ; 2.5$ and $5.0 \mathrm{mg} \mathrm{L}^{-1}$, respectively. However, there was no difference in As absorption in the two latter treatments (Figure 2). Salvinia minima showed a potential similar to that of A. caroliniana in terms of As removal, accumulating $0.061,0.083$ and $0.200 \mathrm{mg} \mathrm{g} \mathrm{DM}^{-1}$ on average, in the $0.5,2.5$ and $5.0 \mathrm{mg} \mathrm{L}^{-1}$ treatments, respectively. This species showed the same potential for As removal when exposed to concentrations of 0.5 and $2.5 \mathrm{mg} \mathrm{L}^{-1}$ (Figure 2). Azolla caroliniana absorbed more than $S$. minima in the 0.5 and $2.5 \mathrm{mg} \mathrm{L}^{-1}$ treatments but was less efficient when submitted to the treatment with greater As concentration $\left(5.0 \mathrm{mg} \mathrm{L}^{-1}\right)$.

"Ideal" plants for use in remediation of polluted environments should be able to remove and tolerate high amounts of contaminants. Barker et al. (2000) considered that a plant was a hyperaccumulator when it accumulated more than $1 \mathrm{mg} \mathrm{g} \mathrm{DM}^{-1}$ of the pollutant. According to this criterion, L. gibba was shown to behave as an As hyperaccumulator in the present study, while A. caroliniana and S. minima did not show the same potentials. Lemna gibba was effective in tolerating also $\mathrm{Cu}$ and $\mathrm{Ni}$ at concentrations $\leq 0.3$ and $\leq 0.5 \mathrm{mg} \mathrm{L}^{-1}$, respectively; the LCI (lowest concentration that

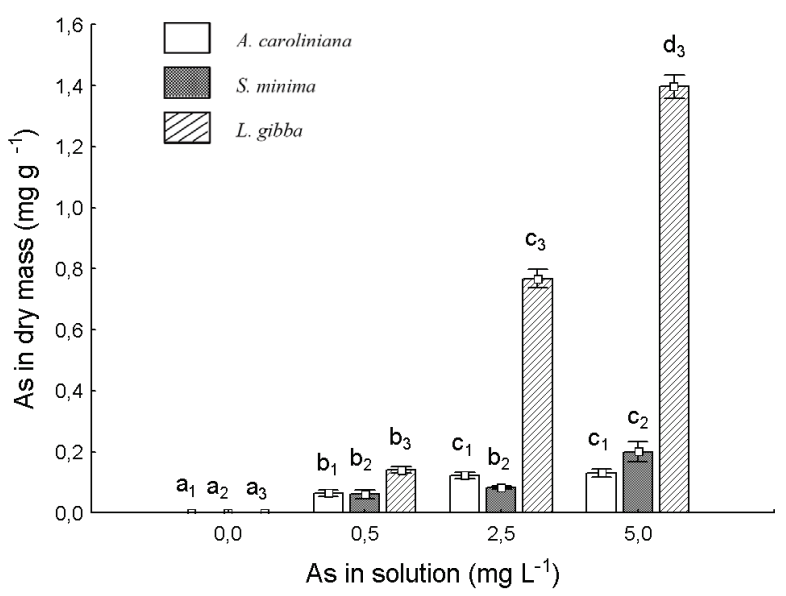

Figure 2 - Arsenic (As) concentration accumulated by the macrophytes in the different treatments. Bars represent standard errors. Different letters indicate different means by Tukey test. cause complete inhibition) was equal 0.5 and $1.0 \mathrm{mg} \mathrm{L}^{-1}$, respectively, in the presence of these pollutants (Khellaf \& Zerdaoui, 2010).

\section{As removal efficiency from the solution}

In terms of efficiency in removing As from the solution, that is, the percentage of As that the species removed from the solution, a decrease in the efficiency of the plants was observed along with the increase in the availability of As (Anova, $\mathrm{df}=2 ;$ A. caroliniana: $\mathrm{F}=21.63, \mathrm{p}=0.000105$, S. minima: $\mathrm{F}=14.37$, $\mathrm{p}=0.000653$ and $L$. gibba: $\mathrm{F}=27.96, \mathrm{p}=0.00003)$.

Lemna gibba, especially, had a greater potential for removing As in solution as compared to the other two species, confirming the assertion of several studies about the great potential of Lemnaceas to remove contaminants from the environment (Jain et al., 1990; Zayed et al., 1998; Axtell et al., 2003; Mkandawire \& Dudel, 2005).

When exposed to $0.5 \mathrm{mg} \mathrm{L}^{-1} \mathrm{As}$ concentration, the three species were efficient in removing As from solution, with L. gibba having the best potential, removing $4.4 \%$ As from the environment. At $0.5 \mathrm{mg} \mathrm{L}^{-1}$ concentration (Figure 3), the performance of A. caroliniana and S. minima was similar, removing $2.5 \%$ and $2.24 \%$ As from solution, respectively. Also in other concentrations, L. gibba was more efficient.

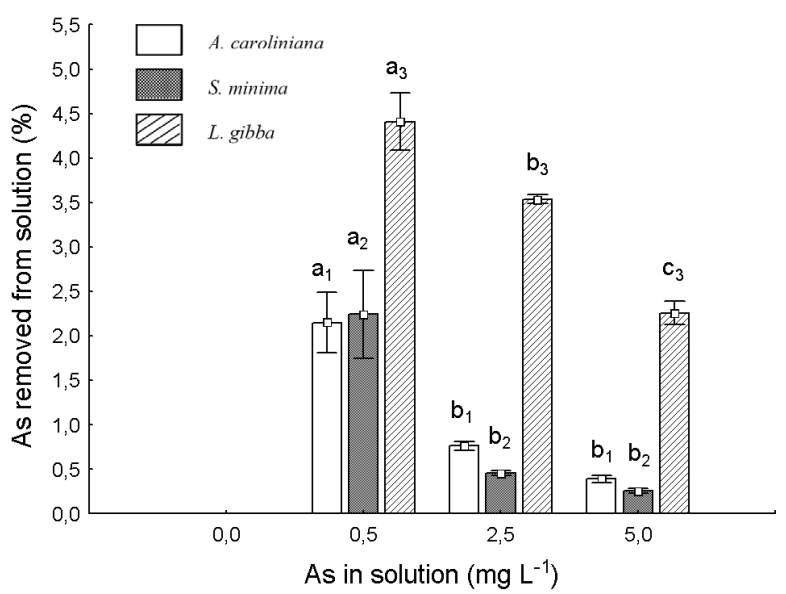

Figure 3 - Arsenic removal efficiency (\%) from the solution by the plants in the different treatments. Bars represent standard errors. Different letters represent different means by Tukey test. 
Several species have been studied to assess their potential in As removal from water. In Venezuela, the rate of As removal for Lemna minor was $140 \mathrm{mg}$ As/ha (day) with a removal recovery of $5 \%$, while Water Hyacinth had a removal rate of $600 \mathrm{mg} \mathrm{As} \mathrm{ha}^{-1}$ (day) and a removal recovery of $18 \%$, under the conditions of the assay (Alvarado et al., 2008). The values shown by the species were lower than the mean registered for $L$. gibba (1.397 $\mathrm{mg} \mathrm{g} \mathrm{DM}^{-1}$ ) in this study, confirming the potential of this species for As removal from the environment.

\section{Arsenate and phosphate competition}

The higher $\mathrm{PO}_{4}{ }^{3-}$ concentration in solution the lower As was absorbed by the macrophytes. The absorption curve followed a negative exponential pattern for the three species investigated (Figures 4, 5 and 6). Azolla caroliniana and S. minima had a decrease in As absorption as well as an increase in the concentration of phosphate in solution. Lemna gibba had the same pattern, but it was able to remove As even when exposed to the higher concentration of phosphate $\left(0.25 \mu \mathrm{mol} \mathrm{L}^{-1}\right)$, surpassing the potential of $A$. caroliniana and $S$. minima. Arsenic absorption by L. gibba was approximately 10 -fold higher when exposed to $0.008 \mu \mathrm{mol} \mathrm{L}^{-1}$ phosphate concentration than to $0.25 \mu \mathrm{mol} \mathrm{L}^{-1}$ concentration, which was used as a standard in all the experiments in this study. Azolla caroliniana and S. minima plants respectively removed 12 and six-fold more As from the solution when exposed to $0.008 \mu \mathrm{mol} \mathrm{L}^{-1}$ phosphate solution than when they were exposed to solution with arsenate concentration equal to that of the phosphate $\left(0.031 \mu \mathrm{mol} \mathrm{L}^{-1}\right)$.

Regarding the influence of phosphate on As removal, the higher the phosphate concentration in solution, the lower the As absorption by the three species. Arsenic accumulation in L. gibba is correlated negatively with phosphate concentrations, because of the fact that the dominant form of AS (V) under oxic conditions is an analog of phosphate; thus, they compete for the same uptake carriers in the plasmalemma (Mkandawire \& Dudel, 2005; Rahman \& Hasegawa, 2011) Once absorbed, arsenate continues competing with the phosphate

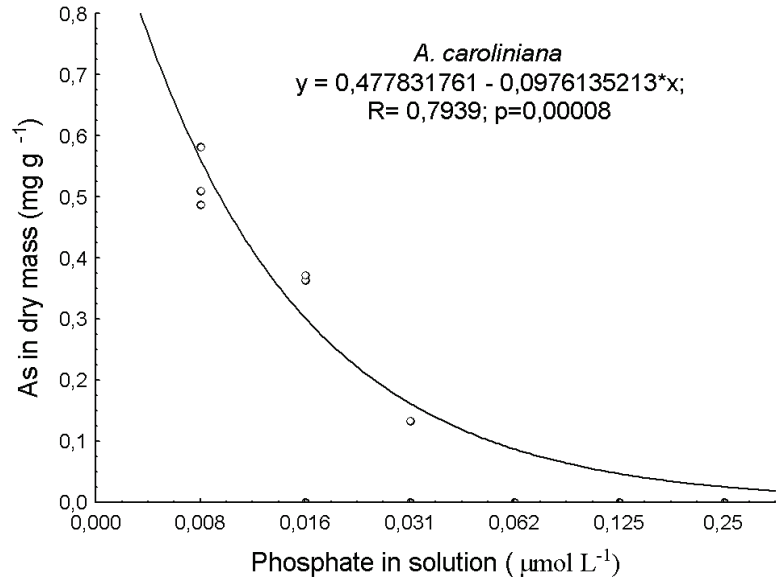

Figure 4 - Arsenic (As) absorption by A. caroliniana under different phosphate amounts in the solution.

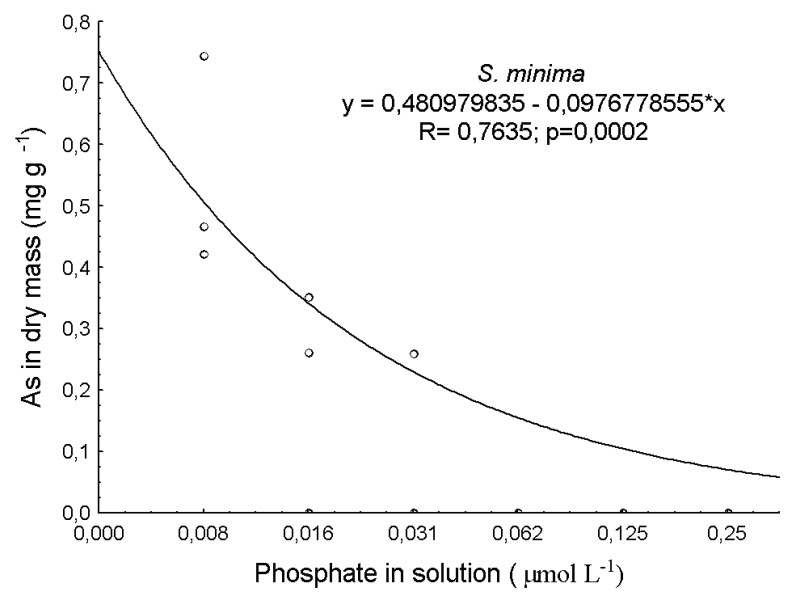

Figure 5 - Arsenic (As) absorption by S. minima under different phosphate amounts in the solution.

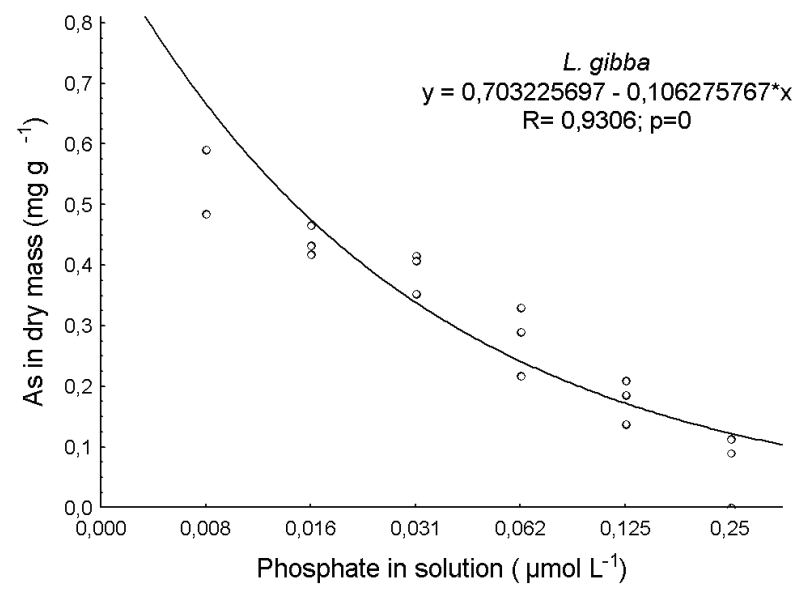

Figure 6 - Arsenic (As) absorption by L. gibba under different phosphate amounts in the solution.

Planta Daninha, Viçosa-MG, v. 30, n. 4, p. 683-696, 2012 
for the same linking sites, affecting plant metabolism e.g. damaging phosphatesugar production; damaging photosynthesis metabolites and respiration; altering the phospholipid components of plant membranes and affecting ATP, DNA and RNA metabolism (Taiz \& Zeiger, 1991). Therefore the typical symptoms of As toxicity closely remember the symptoms of phosphate deficiency such as necrosis, chlorosis and low fresh and dry mass gain (Sing et al. 2006).

In 24 hours' exposure to As, $A$. caroliniana and $S$. minima did not remove the metalloid from the solution containing $0.062 \mu \mathrm{mol} \mathrm{L}-1$ phosphate, showing that when phosphate concentration was greater than that of As in solution, there occurred a preferential phosphate absorption. However, in solution with $0.008 \mu \mathrm{mol} \mathrm{L}^{-1}$ phosphate, S. minima removed six-fold more As than the plants exposed to solution with an identical amount of As and phosphate. Those values were higher than the ones reported by Hoffmann et al. (2004). Under the same experimental conditions, A. caroliniana removed 12 -fold more As when in solution with a lower phosphate concentration. These two species have a potential to accumulate As when cultivated in solution with low phosphate concentration, but they were probably subjected to the toxic effects of the metalloid.

Out of the three species, only L. gibba accumulated As significantly when exposed to $0.25 \mu \mathrm{mol} \mathrm{L}-1$ phosphate (standard concentration used in the experiments). At this concentration, L. gibba accumulated about 10-fold less As than when exposed to $0.008 \mu \mathrm{mol} \mathrm{L}^{-1}$ phosphate, corroborating the data of Mkandawire et al. (2004). In the present study, $L$. gibba removed about $4 \%$ As from the solution containing $0.25 \mu \mathrm{mol} \mathrm{L}^{-1}$ phosphate, whereas in solution without phosphate it removed about 40\% As from the solution (Mkandawire et al., 2004), showing its potential for extracting the metalloid from the environment.

\section{Total pigment content}

The As in solution did not alter the total chlorophyll and carotenoid contents in A. caroliniana, (Anova, $\mathrm{df}=3$; chlorophyll:
$\mathrm{F}=1.9, \mathrm{p}=0.202$; carotenoids: $\mathrm{F}=2.33, \mathrm{p}=0.151$ ). However, As in solution influenced the anthocyanin contents in this species (Anova, $\mathrm{df}=3, \mathrm{~F}=6.05, \mathrm{p}=0.019)$. A. caroliniana exposed to $5.0 \mathrm{mg} \mathrm{L}^{-1}$ As showed optical densities (OD) varying from 0.226 to $512 \mathrm{~nm}$ per gram fresh mass. This value was greater than the results shown by control plants and also for the plants exposed to 0.5 and $2.5 \mathrm{mg} \mathrm{L}^{-1} \mathrm{As}$, respectively (Figure 7). Lemna gibba total chlorophyll and carotenoid content as influenced by As in solution (chlorophyll: Anova, $\mathrm{df}=3, \mathrm{~F}=13.38$, $\mathrm{p}=0.002$; carotenoids: Anova, $\mathrm{df}=3, \mathrm{~F}=12.138$, $\mathrm{p}=0.002)$. The greater the amount of As in solution, the lower the chlorophyll contents in L. gibba (Figure 8). The plants exposed to 0.5 and $2.5 \mathrm{mg} \mathrm{L}^{-1}$ As showed 0.219 , 0.287 and $0.233 \mathrm{mg}$ carotenoids per gram of $F M$, respectively. These values were considered equal and superior to the value of $0.414 \mathrm{mg} \mathrm{g} \mathrm{FM}^{-1}$ observed in plants exposed to $5.0 \mathrm{mg} \mathrm{L}^{-1}$ As. This fact was shown by the occurrence of chlorosis in the leaves of this plant. It is suggested that As affects total chlorophyll synthesis, a fact that has also been reported for Pteris ensiformis (Sing et al., 2006), Zea mays (Jain \& Gadre, 1997) and Trifolium pratense (Mascher et al., 2002). The As in the plant tissues probably affected total chlorophyll contents because of its competition with phosphate.

The carotenoid content in L. gibba was also affected by high As concentration. Carotenoids are accessory pigments fundamental to the photosynthesis process. Thus, As in L. gibba tissues probably affected the tilacoid membranes and carotenoid synthesis, damaging the photosynthetic process. The low total chlorophyll and carotenoid content detected in $L$. gibba could possibly account for the low fresh and dry mass gain of the plants exposed to $5.0 \mathrm{mg} \mathrm{L}^{-1} \mathrm{As}$.

The total chlorophyll content of A. caroliniana, unlike that of $L$. gibba, was not affected by As. This fact may be explained by the lower As absorption by this pteridophyte. In other pteridophytes, however, exposure to As resulted in increased chlorophyll and carotenoid production, in Pteris vittata, and a decrease in the content of these pigments in Pteris ensiformis (Sing et al., 2006). In the biotransformation test, the chlorophyll 


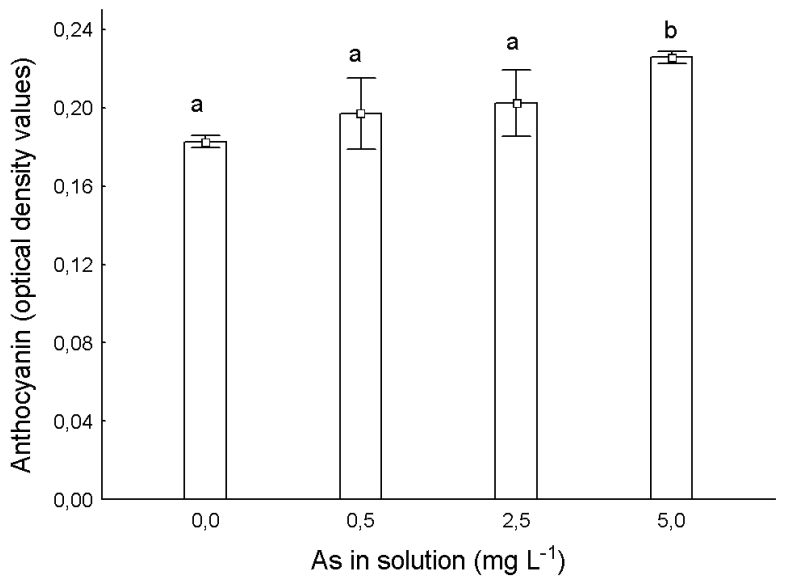

Figure 7 - Anthocyanin content in A. caroliniana exposed to different As concentrations. Bars represent standard errors. Different letters represent different means by Tukey test.

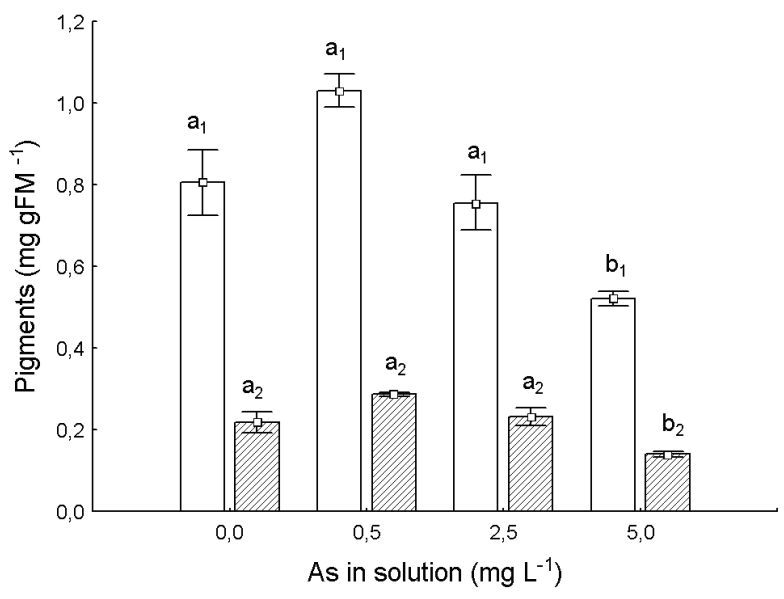

Figure 8 - Total chlorophyll and carotenoid content in L. gibba exposed to different As concentrations. Bars represent standard errors. Different letters represent different means (Tukey test).

contents of Chlamydomonas reinhardtii cells were reduced to zero in the presence of As $(\mathrm{V})$, indicating that such cells were unable to grow under $\geq 0.5 \mathrm{mM}$ after $12 \mathrm{~h}$ exposure (Miyashita et al., 2011).

\section{Symptomatology}

The aquatic macrophytes exhibited characteristic toxicity symptoms when exposed to the $2.5 \mathrm{mg} \mathrm{L}^{-1}$ and $5.0 \mathrm{mg} \mathrm{L}^{-1} \mathrm{As}$. The edges of $A$. caroliniana leaves turned purple after the third day of exposure. Salvinia minima had margin necrosis on the floating leaves even though they were able to produce offpring and release daughter plants, free of any visual symptoms. Lemna gibba presented a decrease in size and an increase in incidence of chloritic plants (Figure 9). These symptoms corroborate the data obtained by Sing et al. (2006), Otzurk et al. (2010), Khellaf \& Zerdaoui, (2010).

At ultrastructural level, the leaves of A. caroliniana plants exposed to $5.0 \mathrm{mg} \mathrm{L}^{-1} \mathrm{As}$ have disorganized and plasmolytic epiderms cells that make the leaf edges curl. No symbiotic cianobacteria colony was observed living inside the leaves. The L. gibba ultrastructure treated with $5.0 \mathrm{mg} \mathrm{L}^{-1} \mathrm{As}$ showed epidermis with disorganized and plasmolytic cells and a great quantity of wax removed from the adaxial and abaxial surfaces. Most stomata on the adaxial surface remained closed, unlike those observed in the control plants (Figure 10).

The three species studied showed typical toxicity symptoms caused by the metalloid, such as necrosis, chlorosis and low fresh and dry mass gain. However, some toxicity symptoms were specific to each species, such as leaf purpling in A. caroliniana, leaf necrosis in $S$. minima leaves and decrease in leaf size in L. gibba.

The A. caroliniana anthocyanin content increased upon exposure to high As concentration, leading to a purplish color of the leaf edges. This can be explained by the fact that plants with phosphate deficiency can produce anthocyanin, resulting in purple coloring in the leaves (Taiz \& Zeiger, 1991; Marschener, 1995). Anthocyanin is a secondary metabolite that can be produced in response to oxidative stress, performing important protection roles (Taiz \& Zeiger, 1991; WinkelShirley, 2002). At $5.0 \mathrm{mg} \mathrm{L}^{-1} \mathrm{As}$, the leaves may also turn purple as a result of nitrogen deficiency. The colonies of cianobacteria, Anabaena genus, present in the lower lobes of A. caroliniana leaves, are nitrogen fixers and thrive in symbiosis with the pteridophytes. The A. caroliniana leaves were completely damaged, and the presence of cianobacteria was not detected; hence, the symbiotic relationship was certainly damaged. The 

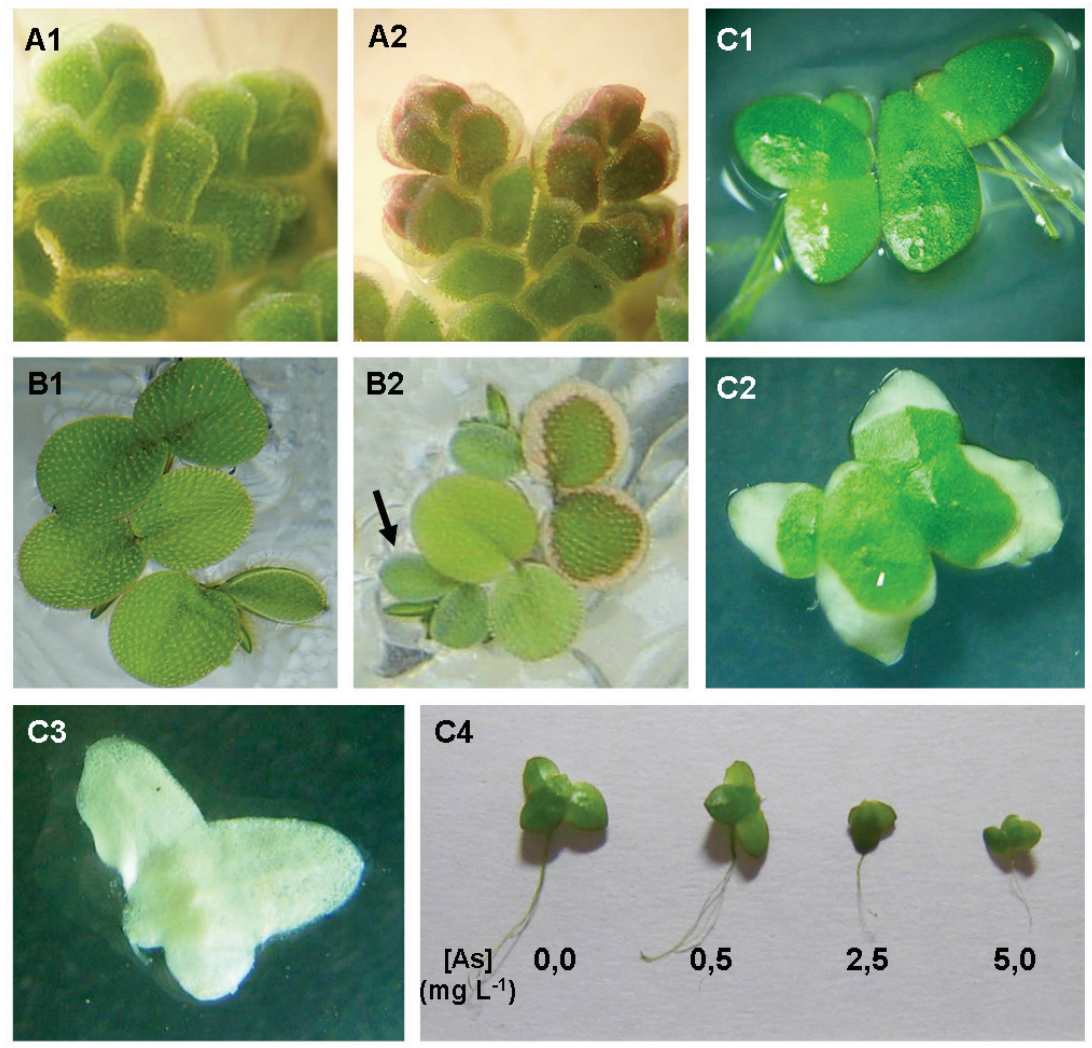

Figure 9 - Symptomatology of plants exposed to As. A1- A. caroliniana: healthy leaves; A2 - anthocyanin accumulation in A. caroliniana exposed to $5.0 \mathrm{mg} \mathrm{L}^{-1}$ As (Arrow); B1 - S. minima: healthy leaves; B2 - leaf necrosis. The arrow indicates healthy daughter plants; C1 - L. gibba: healthy leaves; C2 and C3: L. gibba chlorosis process; C4 - Reduction in leaf size of $L$. gibba exposed to different As concentrations.

damage to the nitrogen supply to the A. caroliniana plants may have led the pteridophyte to produce anthocyanin that reflected the symptoms showing nitrogen deficiency.

The low potential of As accumulation shown by $S$. minima and the appearance of necrosis and chlorosis on the second day of exposure to As corroborated data reported by Hoffmann et al. (2004). In spite of the symptomatology exhibited by the plants, healthy daughter plants were emitted. Therefore, it is probable that this potential was related to phosphorus $(\mathrm{P})$ mobility in the plant tissues. Phosphorus is a mobile nutrient and may be translocated from older to younger leaves, and, thus, deficiency symptoms are first visualized on the older leaves. Furthermore, when plants that propagate vegetatively are exposed to stressful environments, the mother plants give nutritional support to the daughter ones so that they can grow under less stressful conditions (Outridge et al., 1991). Another hypothesis is that $S$. minima daughter plants underwent an acclimation process in the contaminated environment. This process may involve the production of phytochelatin and thiols induced by exposure to the metal. The increase in these substances in the daughter plants may occur because of translocation of substances from the mother plant or as a result of new production in response to the metal translocation. This phenomenon has been observed in S. minima exposed to different cadmium concentrations by Outridge \& Hutchinson (1991) and Outridge et al. (1991).

In spite of the potential presented by L. gibba to remove As from the environment, a decrease was observed in the leaf size of plants exposed to high As concentration. 

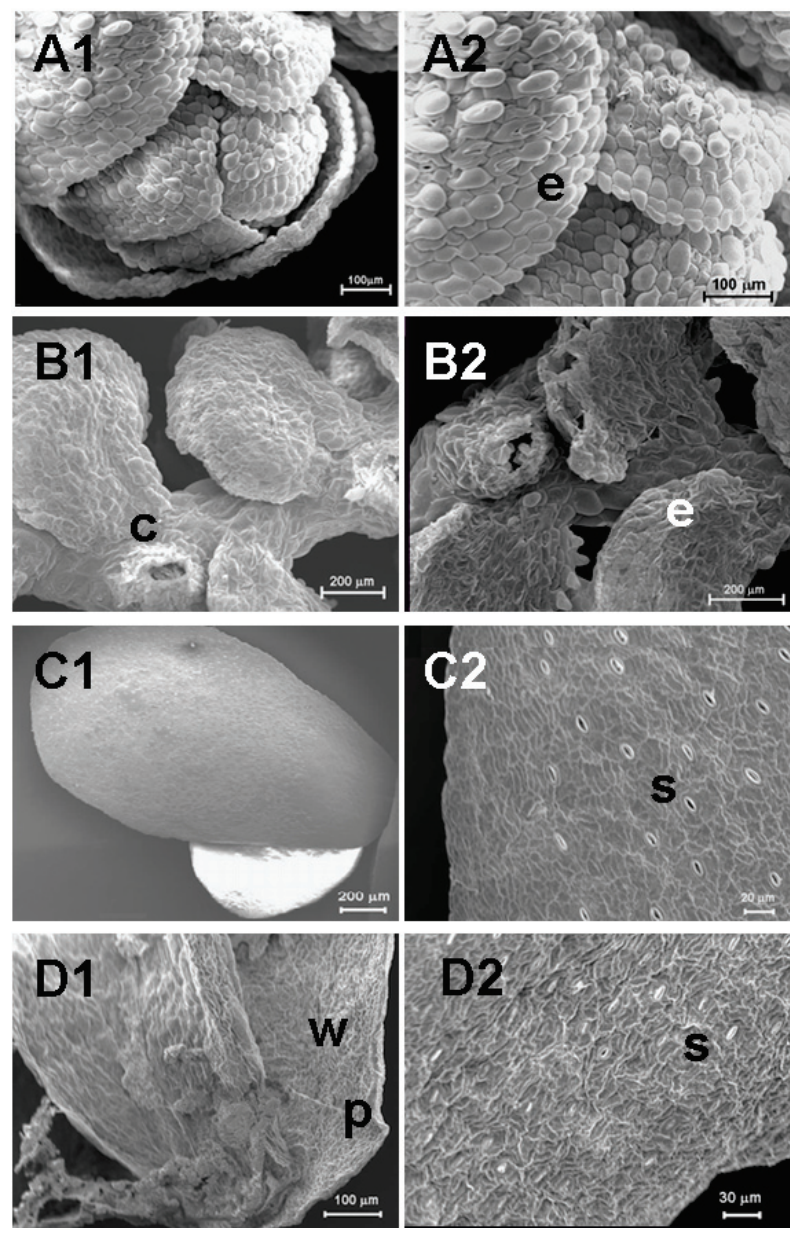

Figura 10 - Scanning electronic microscopy. A: A. caroliniana cultivated in Hoagland solution for six days. A1: Detail of young and healthy leaf edges. A2: Details of normal and turgid epidermis cells of healthy leaves (e). B: A. caroliniana cultivated in Hoagland solution containing $5.0 \mathrm{mg} \mathrm{L}^{-1}$ As (5 days' exposure). B1: Leaf abaxial region, showing absence of cianobacteria (c) and with cianobacteria?. B2: Disorganized and plasmolytic epidermis cells ( $\mathrm{p}$ ) and curled leaf edges. C: L. gibba cultivated in Hoagland solution for six days. C1: General view of the adaxial leaf surface. C2: Detail of the epidermis with turgid cells and normal stomata (s). D: L. gibba cultivated in Hoagland solution containing 5 mg L-1 As (6 days' exposure). D1: Abaxial surface with curled edges (b), plasmolytic cells and epicuticule wax removed (w). D2: Adaxial surface with disorganized plasmolytic cell, closed stomata (s) and epicuticule wax removed (w).

Mkandawire et al. (2004, 2005) suggested that reduction in the leaf size of $L$. gibba was a survival strategy when the plants were submitted to unfavorable environmental conditions. Decrease in the individual size may be related to a response to nutrient shortage in the environment (Damuth, 2001; Mkandawire et al., 2005).

One of the desirable characteristics for remediation purposes is a high biomass production (Pilon-Smits \& Pilon, 2002; Lasat, 2002; Adler et al., 2003; Pilon-Smits, 2005). This characteristic was observed in this study for the three species investigated, when grown in nutrient solution with As. However, L. gibba was the only macrophyte that showed a potential phytoremediation for As, behaving as an hyperaccumulator of this metalloid. Furthermore, the performance of this species was optimized under conditions of low phosphate availability.

The decrease in the removal efficiency of As in solution along with high concentrations of the metalloid showed the viability of using the phytoremediation technique, mainly in environments with medium to low pollutant concentration (Schnoor, 1997; Lasat, 2002; Pilon-Smits \& Pilon, 2002; Williams, 2002; Tsao, 2003; Pilon-Smits, 2005).

A. caroliniana, L. gibba and S. minima showed a decrease in fresh and dry mass gain when exposed to high As concentrations, and different removal efficiency of the metalloid in solution. $L$. gibba showed the greatest potential to remove As from solution, although As decreased its total chlorophyll and carotenoid content. Arsenic accumulation by the plants was higher along with the increase in the concentration of the metalloid in solution. However, the removal efficiency decreased when the plants were exposed to high concentrations of the metalloid, revealing the limitation of the use of the species in remediating highly impacted aquatic environments.

The potential of the plants to absorb As from solution increased as the amounts of phosphate decreased in the medium. Lemna gibba is considered an As hyperaccumulator. It is suggested that the phytoremediation potential of this species could be optimized with the use of molecular techniques (Chen et al., 2002) as recommended for As removal in environments with low phosphate concentrations (Meharg \& Macnair, 1992; Cao et al., 2003). 


\section{ACKNOWLEDGMENTS}

The authors would like to thank the Federal University of Viçosa and the Brazilian Agricultural Research Corporation-Maize and Sorghum, for providing infrastructure and financial support. F. Guimarães would like to thank the Brazilian Agricultural Research Corporation for a two-year fellowship, and F.C.C. Barreto and J. E. Peçanha, students of the Federal University of Viçosa, for the several helpful discussions in the course of this work.

\section{LITERATURE CITED}

ADLER, P. R. et al. Mechanistic approach to phytoremediation of water. Ecol. Eng., v. 20, n. 3, p. 251-264, 2003.

AKSORN, E.; VISOOTTIVISETH, P. Selection of suitable emergent plants for removal of arsenic from arsenic contamined water. Sci. Asia, v. 30, n. 2, p. 105-113, 2004

ALVARADO, S. et al. Arsenic removal from waters by bioremediation with the aquatic plants Water Hyacinth (Eichhornia crassipes) and Lesser Duckweed (Lemna minor). Biores. Technol., v. 99, n. 17, p. 8436-8440, 2008.

AXTELL, N. R.; STERNBERG, S. P. K.; CLAUSSEN, K. Lead and nickel removal using Microspora and Lemna minor. Biores. Technol., v. 89, n. 1, p. 41-48, 2003.

BARKER, A. J. M. et al. Metal hyperaccumulator plants: A review of the ecology and physiology of a biological resource for phytoremediation of metal-polluted soils. In: TERRY, N.; BAÑUELOS, G. (Ed.). Phytoremediation of contaminated soil and water. Boca Raton: Lewis Publishers, 2000. p. 85107.

CAO, X.; MA, L. Q.; SHIRALIPOUR, A. Effects of compost and phosphate amendments on arsenic mobility in soils and arsenic uptake by the hyperaccumulator Pteris vittata L. Environ. Pollution, v. 126, n. 1, p. 157-167, 2003.

CEDERGREEN, N.; STREIBIG, J. C.; SPLIID, N. H. Sensitivity of aquatic plants to the herbicide metsulfuronmethyl. Ecotoxicol. Environ. Saf., v. 57, n. 1, p. 153-161, 2004.

CHEN, T. et al. Effect of phosphorus on arsenic accumulation in As-hyperaccumulator Pteris vittata L. and its implication. Chinese Sci. B., v. 47, n. 22, p. 1876-1879, 2002.

DAMUTH, J. Scaling of growth: Plants and animals are not so different. PNAS, v. 98, n. 5, p. 2113-2114, 2001.

Planta Daninha, Viçosa-MG, v. 30, n. 4, p. 683-696, 2012
DEMBITSKY, V. M.; REZANKA, T. Natural occurrence of arseno compounds in plants, lichens, fungi, algal species, and microorganisms. Plant Sci., v. 165, n. 6, p. 1177-1192, 2003.

DIONÍSIO, A. G. G.; GONZÁLES, M. H.; NÓBREGA, J. A. Determinação de arsênio em amostras da cadeia produtiva de frango de corte por espectrometria de absorção atômica com forno de grafite. Quim. Nova, v. 34, n. 1, p. 49-52, 2011.

GRAEME, K. A.; POLLACK, C. V. J. Heavy metal toxicity Part I: arsenic and mercury. J. Emerg. Med., v. 16, n. 1, p. $45-56,1998$.

HARTLEY-WHITAKER, J. et al. Phytochelatins are involved in differential arsenate tolerance in Holcus lanatus. Plant Physiol., v. 126, n. 1, p. 299-306, 2001.

HOAGLAND, D. R.; ARNON, D. I. The water - culture method for growing plants without soil. Berkeley: Califórnia Agricultural Experiment Station, 1950. 32 p. (Circular, 347)

HOFFMANN T.; KUTTER, C.; SANTAMARÍA, J. Capacity of Salvinia minima Baker to tolerate and accumulate As and Pb. Eng. Life Sci., v. 4, n. 1, p. 61-65, 2004.

JAIN, M.; GADRE, R. P. Effect of as on chlorophyll and protein contents and enzymic activities in greening maize tissues. Water Air Soil Pollut., v. 93, n. 1-4, p. 109-115, 1997.

JAIN, S. K.; VASUDEVAN, P.; JHA, N. K. Azolla pinnata R. $\mathrm{Br}$. and Lemna minor $\mathrm{L}$. for removal of lead and zinc from polluted water. Water Res., v. 24, n. 2, p. 177-183, 1990.

JACQUES, R. J. S. et al. Bioremediation of soils contaminated with polycyclic aromatic hydrocarbons. Ci. Rural, v. 37, n. 4, p. 1192-1201, 2007.

KAMPERIDOU, I.; VASILAKAKIS, M. Effect of propagation material on some quality attributes of strawberry fruit (Fragaria x ananassa, var. Selva). Sci. Hortic., v. 107, n. 1, p. 137-142, 2006.

KHELLAF, N.; ZERDAOUI, M. Growth response of the duckweed Lemna gibba L. to copper and nickel phytoaccumulation. Ecotoxicology, v. 19, n. 8, p. 1363-1368, 2010.

LASAT, M. M. Phytoextration of toxic metals: A review of biological mechanisms. J. Environ. Qual., v. 31, n. 1, p. 109 120, 2002.

LICHTHENTHALER, H. K. Chlorophylls and carotenoids: pigments of photosynthetic biomembranes. In: COLOWICK, S. P.; KAPLAN, N. O. (Ed.). Methods in enzimology San Diego: Academic Press, 1987. p. 350-382. 
MARSCHENER, H. Mineral nutrition of higher plants. London: Academic Press, 1995. 889 p.

MASCHER, R. et al. Arsenate toxicity: effects on oxidative stress response molecules and enzymes in red clover plants. Plant Sci., v. 163, n. 5, p. 961-969, 2002.

MATSCHULLAT, J. et al. Human and environmental contamination in the Iron Quadrangle, Brazil. Appl. Geochem., v. 15, n. 1, p. 193-202, 2000.

MEHARG, A. A.; HARTLEY-WHITAKER, J. Arsenic uptake and metabolism in arsenic resistant and nonresistant plant species. New Phytol., v. 154, n. 1, p. 29-43, 2002.

MEHARG, A. A.; MACNAIR, M. R. Suppression of the high affinityphosphate uptake system: a mechanism of arsenate tolerance in Holcus lanatus L. J. Exper. Bot., v. 43, n. 4, p. 519-524, 1992.

MIYASHITA, S. et al. Rapid biotransformation of Arsenate into oxo-arsenosugars by a freshwater unicellular green algae Chlamydonas reinhardtii. Biosci. Biotechnol. Biochem., v. 75 , n. 3, p. 522-530, 2011.

MKANDAWIRE, M.; DUDEL, E. G. Accumulation of arsenic in Lemna gibba L. (duckweed) in tailing waters of two abandoned uranium mining sites in Saxony, Germany. Sci. Total Environ., v. 336, n. 1, p. 81-89, 2005.

MKANDAWIRE, M. et al. Toxicity of arsenic species to Lemna gibba L. and the influence of phosphate on arsenic bioavailability. Environ. Toxicol., v. 19, n. 1, p. 26-34, 2004.

OLIVEIRA, L. F. C. et al. Isotermas de sorção de metais pesados em solos do cerrado de Goiás. R. Bras. Eng. Agríc. Amb., v. 14, n. 7, p. 776-782, 2010.

OTZURK, F. et al. Arsenic accumulation and biological responses of watercress (Nasturtium officinale R. Br.) exposed to arsenite. Environ. Exper. Bot., v. 69, n. 1, p. 167-174, 2010.

OUTRIDGE, P. M.; HUTCHINSON, T. C. Induction of cadmium tolerance by acclimation transferred between ramets of clonal fern Salvinia minima Baker. New Phytol., v. 117, n. 4, p. 597-605, 1991.

OUTRIDGE, P. M.; RAUSER, W. E.; HUTCHINSON, T. C. Changes in metal-binding peptides due to acclimation to cadmium transferred between ramets of Salvinia minima. Oecologia, v. 88, n. 1, p. 109-115, 1991.

PILON-SMITS, E. Phytoremediation. Ann. Rev. Plant. Physiol. Plant Molec. Biol., v. 56, n. 1, p. 15-39, 2005.

PILON-SMITS, E.; PILON, M. Phytoremediation of metals using transgenic plants. Crit. Rev. Plant Sci., v. 2, n. 5, p. 439-456, 2002.
QIAN, J. H. et al. Phytoaccumulation of trace elements by wetland plants: III. Uptake and accumulation of ten trace elements by twelve plant species. J. Environ. Qual., v. 28, n. 5, p. 1448-1455, 1999.

RAGHOthama, K. G. Phosphate acquisition. Ann. Rev. Plant Physiol. Plant. Molec. Biol., v. 50, p. 665-693, 1999.

RAGHOTHAMA, K. G. Phosphate transport and signaling. Curr. Opin. Plant Biol., v. 3, n. 1, p. 182-187, 2000.

RAHMAN, M. A.; HASEGAWA, H. Aquatic arsenic: Phytoremediation using floating macrophytes.

Chemosphere, v. 83, n. 5, p. 633-646, 2011.

RODRIGUES, A. S. L.; MALAFAIA, G. Efeitos da exposição ao arsênio na saúde humana. Ver. Saúde. Com., v. 4, n. 2, p. 148-159, 2008.

RODRIGUES, A. S. L.; MALAFAIA, G. A importância dos estudos sobre a contaminação por arsênio na saúde pública. SaBios: Rev. Saúde Biol., v. 5, n. 2, p. 34-38, 2010.

SAMECKA-CYMERMAN, A.; KEMPERS, A. J. Bioaccumulation of heavy metals by aquatic macrophytes around Wroclaw. Ecotoxicol. Environ. Saf., v. 35, n. 3, p. 242-247, 1996.

SCHNOOR, J. L. Phytoremediation. Techonol. Eval. Rep., v. 7; n. 1, p. 1-31, 1997.

SING, N. et al. Metabolic adaptations to arsenic-induced oxidative stress in Pteris vittata L. and Pteris ensiformis L. Plant Sci., v. 170, n. 2, p. 274-282, 2006.

SIVACI, E. R.; SIVACI, A.; SOKMEN, M. Biosorpition of cadimium by Myriophyllum spicatum L. and Myriophyllum triphyllum orchard. Chemosphere, v. 56, n. 11, p. 1043-1048, 2004.

TAIZ, L.; ZEIGER, E. Plant physiology. Redwood City: The Benjamim/Cummings Publishing Company, 1991. 565 p.

TRYON, R. M.; TRYON, A. F. Ferns and allied plants with special reference tro Tropical America. New York: Springer-Verlag, 1982. $1985 \mathrm{p}$.

TSAO, D. T. Overview of phytotechnologies. Adv. Biochem. Eng. Biotechnol., v. 78, n. 1, p. 1-50, 2003.

WILLIAMS, J. B. Phytoremediation in wetland ecosystems: progress, problems, and potencial. Crit. Rev. Plant Sci., v. 21 , n. 6 , p. $607-635,2002$.

WINKEL-SHIRLEY, B. Biosynthesis of flavonoids and effects of stress. Plant Biol., v. 5, n. 1, p. 218-223, 2002.

Planta Daninha, Viçosa-MG, v. 30, n. 4, p. 683-696, 2012 
ZAYED, A.; GOWTHAMAN, S.; TERRY, N.

Phytoaccumulation of trace elements by wetland plants: I. Duckweed. J. Environ. Qual., v. 27, n. 3, p. 715-721, 1998.
ZHU, Y-L. et al. Phytoaccumulation of trace elements by wetland plants: II. Water hyacinth. J. Environ. Qual., v. 28, n. 1, p. 339-344, 1999. 